\title{
Liberal or Constrained? Judicial Incorporations of Other Rules of International Law in the UNCLOS and the Application of the "Genuine Link Test"
}

Ke Song*

The UNCLOS regulates complex balance of rights and duties among State parties. Its text was deliberately left vague as a result of compromise between the negotiating parties. To develop the legal norms, judges and arbitrators have referred to other rules of international law through systematic integration, rules of reference, and broad applicable law. However, judicial practice has expanded subject-matter jurisdiction beyond the UNCLOS, causing antinomy between Articles 288, on jurisdiction, and 293 of UNCLOS, on applicable law. Part XV of the UNCLOS has created an invisible community that would ideally lead the UNCLOS Tribunals to develop and follow a pragmatic approach as to the limits of their subject-matter jurisdiction in order to provide for judicial coherence. When interpreting the treaty, the establishment of genuine links between disputes and substantive rules under the UNCLOS is necessary, by which other rules of international law are firmly anchored to the interpreted texts under the UNCLOS.

\section{Keywords}

UNCLOS Dispute Settlement Procedures, Compromissory Clause, Compulsory Jurisdiction, Applicable Law, Genuine Link, Systematic Integration

* Ph.D. candidate at the University of Edinburgh School of Law, UK. LL.M. (CUPL)/LL.M. (Leiden). ORCID: https:// orcid.org/0000-0002-8933-4976. This research was supported by the National Social Science Fund of China, Project No. 19VHQ008 and the Chinese Scholarship Council, Project No. 201707070032. I would express deep thanks to Professor Jianjun Gao, Professor James Harrison, Ms. Whitny Kapa and Dr. Jilu Wu for valuable comments and warm encouragement. Any remaining mistakes are the author's responsibility. The author may be contacted at: ke.song@, ed.ac.uk /Address: Old College, South Bridge, Edinburgh, Scotland, EH8 9YL.

All the websites cited in this article were last visited on May 12, 2020. 


\section{Introduction}

The United Nations Convention on the Law of the Sea ("UNCLOS") ${ }^{1}$ is designed to resolve many long-standing controversies concerning the rights of coastal States and the freedoms of the sea to use the ocean for various purposes including, inter alia, navigation, natural resources, and scientific research. One of the cardinal achievements of the negotiated text is the creation of a uniform system of maritime zones that replaced a plethora of conflicting claims by coastal States, with "universally agreed limits on the territorial sea, the contiguous zone, the exclusive economic zone and the continental shelf."

However, to achieve these compromises, the clear meaning of treaty provisions would become ambiguous to suppress disagreements. ${ }^{3}$ Because the negotiated texts are open-textured and left with inherent flexibility, which are linked more closely to subsequent development through international adjudicatory bodies, courts and tribunals are left with some leeway in interpretation by giving substantive meaning to these provisions when applying them in concrete cases.

Current case law has significantly contributed to the development of the dispute settlement rules and principles of the UNCLOS. ${ }^{4}$ In this regard, the dual functions of the UNCLOS dispute settlement procedures can be considered: first, as a means of maintaining the negotiated text between States through consensus, and second, as a means of adapting to the changing needs of the international community. ${ }^{5}$

In contrast, judicial development of the law of the sea necessarily involves other rules of international law, but it should create a tension between the traditional principles and other rules of international law. This research will mainly consider

1 United Nations Convention on the Law of the Sea, Dec. 10, 1982, 1833 U.N.T.S. 397.

2 T. Koh, A Constitution for Oceans (Dec. 11, 1982), available at http://www.un.org/depts/los/convention_agreements/ texts/koh_english.pdf.

3 I. Shearer, Oceans Management Challenges for the Law of the Sea in the First Decade of the 21st Century, in OCEANS Management in the 21st Century: Institutional Frameworks and Responses 4 (A. Elferink \& D. Rothwell eds., 2004). See also B. Oxman, Observations on Vessel Release under the United Nations Convention on the Law of the Sea, 11 Int'L J. Mar. \& CoAstal L. 202 (1996).

4 D. Anderson, The Tribunal's Jurisprudence and Its Contribution to the Rule of Law, in The CONTRIBUTION OF THE International Tribunal for the Law of the Sea to the Rule of Law 1996-2016, 3-9 (ITLOS ed., 2018). See also P. Rao \& P. Gautier, The International Tribunal for the Law of the Sea: Law, Practice and Procedure (2019).

5 N. Klein, Expansions and Restrictions in the UNCLOS Dispute Settlement Regime: Lessons from Recent Decisions, 15 ChInESE J. INT'L L. 403-15 (2016). See also M. Wood, The International Tribunal for the Law of the Sea and General International Law, 22 InT'L J. MAR. \& COASTAL L. 351-67 (2007); A. Boyle, UNCLOS Dispute Settlement and the Uses and Abuses of Part XV, 47 Revue Belge DI 182-204 (2014). 
such tension. ${ }^{6}$

Contrary to the drafters' expectations, judicial incorporation of other rules of international law has caused unreasonable expansion of subject-matter jurisdiction of the UNCLOS, consequently derogating the consensual basis of the UNCLOS Tribunals. ${ }^{7}$ In addition, many commentators have predicted that the blurring of the limitations of subject-matter jurisdiction by inconsistent and incoherent jurisprudence of judicial bodies may damage the legitimacy of the UNCLOS dispute settlement procedures as a whole. ${ }^{8}$ In light of these concerns, this article will explore how the UNCLOS Tribunals should promote the consistency and coherence of judicial practice on the limits of subject-matter jurisdiction.

\section{The Approaches of the UNCLOS Tribunals in their Judicial Incorporation of Other Rules of International Law}

As a starting point, it is necessary to discuss how courts and tribunals incorporate other rules of international law in their judicial practice. International adjudicatory bodies are constrained by customary rules of treaty interpretation and application. As a matter of general judicial practice, "it is trite to note that international courts generally go about the business of treaty interpretation in accordance with the rules that have been codified in the Vienna Convention on the Law of Treaties ("VCLT"). In particular, courts and tribunals have taken the novel approach of using systematic integration enshrined under Article 31(3)(c) of the VCLT.

\section{A. Systematic Integration}

Article 31(3)(c) of the VCLT provides that treaty interpretation should take into account "any relevant rules of international law applicable in the relations between

6 P. Tzeng, Jurisdiction and Applicable Law under UNCLOS, 126 YALE L. J. 246 (2016). See also K. Parlett, Beyond the Four Corners of the Convention: Expanding the Scope of Jurisdiction of Law of the Sea Tribunals, 48 OCEAN DEv. \& INT'L L. 294-9 (2017).

7 UNCLOS art. 288 (1). For details, see Tzeng, id. at 246.

8 A. Boyle \& J. Harrison, Judicial Settlement of International Environmental Disputes: Current Problems, 4 J. INT'L Disp. Settlement 255 (2013).

9 C. Brown, A Common Law of International Adjudication 42 (2007). 
the parties,"10 which may be called the principle of "systematic integration.,"11

Systematic integration provides an express justification for international courts and tribunals to interpret legal terms "outside the four corners of a particular treaty to its place in the broader framework of international law, applying general principles of international law."12 The meaning of the treaty provisions are ascertained through allowing courts and tribunals to interpret these legal norms by incorporating other rules of international law. ${ }^{13}$

Systematic integration should have a pervasive impact on interpreting the UNCLOS texts. In practice, the UNCLOS Tribunals have employed this interpretative approach in their judicial reasoning. As noted by the arbitral tribunal in Duzgit Integrity Arbitration, "the exercise of enforcement powers by a [coastal] State in situations where the State derives these powers from provisions of the Convention is also governed by certain rules and principles of general international law, in particular the principle of reasonableness." ${ }^{14}$

The South China Sea Arbitration might be a noticeable example for illuminating the novel use of systematic integration when courts and tribunals deal with issues involving marine environmental protection. In this arbitration, the Philippine submission (No. 11) sought a declaration that: "China has violated its obligations under the Convention to protect and preserve the marine environment at Scarborough Shoal and Second Thomas Shoal." 15 This submission reflects the dispute concerning the application of Articles 192 and 194 of the UNCLOS. ${ }^{16}$ The arbitral tribunal adopted a systematic approach to the interpretation of Article 192, noting that the content of this provision had been informed by the other provisions of Part XII and other applicable rules of international law that the arbitral tribunal termed the "corpus of international law relating to the environment,"17 and incorporated a

10 VCLT art. 31(3)(c).

11 Int'1 Law Comm'n, Rep. on the Work of its Fifty-Eighth Session, U.N. Doc. A/CN/.4/1.682, at 9413 (2006).

12 C. McLachlan, The Principle of Systemic Integration and Article 31(3)(C) of the Vienna Convention, 54 InT'L \& ComP. L. Q. 281 (2005).

13 The method of systematic interpretation is often associated with Article 31(3)(c) of the VCLT, which stated that: "there shall be taken into account, together with the context: [...] (c) any relevant rules of international law applicable in the relations between the parties". For details, see supra note 12, at 9ף 410-480 (2006); supra note 13; D. French, Treaty Interpretation and The Incorporation of Extraneous Legal Rules, 55 INT’L \& COMP. L.Q. 281-314 (2006).

14 Duzgit Integrity Arbitration (Malta v. São Tomé \& Príncipe), PCA Case No. 2014-07. Award (Perm. Ct. Arb. 2016), available at $\mathrm{https}: / /$ pcacases.com/web/sendAttach/1915 [hereinafter Duzgit Integrity Arbitration].

15 The South China Sea Arbitration (Phil. v. China), PCA Case No. 2013-19, Award on Jurisdiction, 101 (Perm. Ct. Arb. 2015), available at https://pcacases.com/web/sendAttach/2579 [hereinafter South China Sea Award on Jurisdiction].

16 Id. at 908.

17 The South China Sea Arbitration (Phil. v. China), PCA Case No. 2013-19, Award, 941 (Perm. Ct. Arb. 2016), available at $\mathrm{https}$ //pcacases.com/web/sendAttach/2086. [hereinafter South China Sea Merit Award] 
due diligence obligation into the general obligation under Article 192. Hence, the elaboration of the general obligation requires flag States to adopt not only appropriate rules and measures, but also a certain level of vigilance in their enforcement and in the exercise of administrative control. ${ }^{18}$

It is worth recalling that at the jurisdictional stage, the arbitral tribunal acknowledged that the dispute contained in the submissions concerned both Articles 192 and 194(5) of the UNCLOS, and the Convention on Biological Diversity ("CBD"). Considering the overlap, the arbitral tribunal still confirmed its jurisdiction. The arbitral tribunal noted that the circumstances of "two treaties bearing upon a particular dispute" could not bar it from exercising jurisdiction over the dispute that traversed the UNCLOS and the CBD, endorsing the jurisprudence of ITLOS in MOX Plant. ${ }^{19}$ At the merit stage, the arbitral tribunal noted that the CBD provides the internationally accepted definition of ecosystem, and thus can give meaning to the Article 194(5) of the UNCLOS. In this manner, the undefined norm 'ecosystem' was interpreted in light of Article 2 of the CBD. ${ }^{20}$

The UNCLOS Tribunals also take a flexible approach to emerging customary rules of international law as interpretative materials. This practice goes beyond systematic integration, which requires the interpretative materials to be binding rules of international law. For example, the term 'urgency' used to indicate one of the requirements for granting provisional measures, ${ }^{21}$ was interpreted in connection with the precautionary approach as a notion in environmental law. As ITLOS stated in its Order in Southern Bluefin Tuna (provisional measures), "in the view of the Tribunal, the parties should in the circumstances act with prudence and caution to ensure that effective conservation measures are taken to prevent serious harm to the stock of southern bluefin tuna."22 Judge Treves in his separate opinion gave an explanation for this approach:

This approach, which may be called precautionary, is hinted at in the Order, in particular in paragraph 77. However, that paragraph refers it to the future conduct of the parties. While, of course, a precautionary approach by parties in their future conduct is necessary, such precautionary approach, in my opinion, is necessary

18 Id. at 944.

19 South China Sea Award on Jurisdiction, ๆฯ 174-178; MOX Plant (Ir. v. U.K.), Case No.10, Order of Dec. 3, 2001, ITLOS Rep. 95, at ๆๆ 48-52.

20 South China Sea Arbitration Merit Award, at 945.

21 UNCLOS art. 290(5).

22 Southern Bluefin Tuna (N.Z. v. Japan; Austl. v. Japan), Case No. 3 \& 4, 1999, Order of Aug. 27, 1999, ITLOS Rep. 280, 97 . [hereinafter Southern Bluefin Tuna] 
also in the assessment by the Tribunal of urgency of the measure it might take. In the present case, it would seem to me that the requirement of urgency is satisfied only in the light of such precautionary approach. ${ }^{23}$

Considering that the normative status of the precautionary approach as a customary rule is highly debatable, it is fully understood that ITLOS is reluctant to use the term "precautionary approach" in the language of the Order and to take a position as to whether the precautionary approach is a binding principle of customary international law. ${ }^{24}$ Judge Treves, in his separate opinion, provided what might be considered a reasonable justification for such reluctance, stating that "a precautionary approach seems to me inherent in the very notion of provisional measures. ${ }^{, 25}$

\section{B. Rules of Reference}

The UNCLOS presupposes the existence of other rules of international law that are of relevance for regulating issues on the law of the sea. This has given rise to formulating a number of rules of reference, described as a "built-in mechanism." However, the applicability, content, and scope of references is a matter of how each provision is interpreted. Over time, the UNCLOS Tribunals have given divergent interpretations of the rules of reference in specific instances.

The arbitral tribunals in Chagos MPA Arbitration and the South China Arbitration have given divergent interpretations over a particular rule of reference under Article 2(3) of the UNCLOS, which reads: "the sovereignty over the territorial sea is exercised subject to this Convention and other rules of international law." ${ }^{26}$ In Chagos MPA Arbitration, the arbitral tribunal held that the "obligation in Article 2(3) is limited to exercising sovereignty subject to the general rules of international law." ${ }^{27}$ In the view of the arbitral tribunal, the so-called Lancaster House Undertakings does not represent part of the general rules of international law for which the Convention creates an obligation of compliance. The arbitral tribunal thus held that Article 2(3) does not form the jurisdictional basis for issues relating to the so-called Lancaster

23 Id. at 8 (seperate opinion by Treves, J.). [Emphasis added]

24 Yoshifumi Tanaka, Rethinking Lex Ferenda in International Adjudication, 51 GER. Y.B. INT'T L. 492 (2008).

25 Southern Bluefin Tuna, 9 (seperate opinion by Treves, J.).

26 UNCLOS art. 2(3). [Emphasis added]

27 The Chagos MPA Arbitration (Mauritius. v. U.K.), PCA Case No. 20111-03, Award, 1516 (Perm. Ct. Arb. 2015), available at https://files.pca-cpa.org/pcadocs/MU-UK\%2020150318\%20Award.pdf. [hereinafter Chagos MPA Arbitration] 
House Undertakings. ${ }^{28}$ In contrast to Chagos MPA Arbitration, in South China Sea Arbitration, the arbitral tribunal gave a conflicting interpretation, maintaining that "other rules of international law" contained in Article 2(3) do not have to be "general rules of international law," thereby affirming its jurisdiction over disputes on traditional fishing rights in territorial seas based on "other rules of international law" contained in Article 2(3) of the UNCLOS. ${ }^{29}$

In ARA Libertad, ${ }^{30}$ disputed parties contested whether the wording of Article 32 of the UNCLOS can be used as a jurisdictional basis for adjudication over customary international law on warship immunities. ITLOS circumvented the issue by confirming its prima facie jurisdiction that a dispute appears to exist between the parties on the interpretation and application of Article 32 of the UNCLOS. ${ }^{31}$ Nonetheless, Judges Wolfrum and Cot, in their joint separate opinion, proposed that "Article 32 constitutes a reference rather than a regulation in itself." In that respect, Article 32 relates to the last preambular paragraph of the Convention: "Affirming that matters not regulated by this Convention continue to be governed by the rules and principles of general international law." 32 They concluded with the opposite view that Article 32 cannot serve as the jurisdictional basis for issues on immunities.

In addition to the rules of references, the UNCLOS Tribunals have employed the concept of applicable law under Article 293 of the UNCLOS for applying other rules of international law. Notably, the UNCLOS Tribunals' application of Article 293 to its consideration of State consent as the basis of jurisdiction has attracted serious criticism.

\section{Broad Applicable Law}

It is a constant litigation strategy for States to resort to Article 293 to persuade the UNCLOS Tribunals to adjudicate disputes that are broader than the UNCLOS. ${ }^{33}$ As famously noted by the arbitral tribunal in MOX Plant,

28 Id. at 517.

29 South China Sea Arbitration Merit Award, ๆ 808.

30 ARA Libertad (Arg. v. Ghana), Case No.20, 2012, Order of Dec.15, 2012, ITLOS Rep. 332. (hereinafter ARA Libertad)

31 “ARA Libertad” at 9 \% 65-66.

32 “ARA Libertad," at 9 41. (Joint separate opinion of Wolfrum and Cot J.).

33 M/V "Saiga" (No.2) Case (St. Vincent v. Guinea), Case No.2, Judgement of July 1, 1999, ITLOS Rep. 10 [hereinafter M/V "Saiga" (No.2)]; Guyana v. Suriname Arbitration, PCA Case No. 2004-04. Award (Perm. Ct. Arb. 2007), available at https://pcacases.com/web/sendAttach/902 [hereinafter Guyana v. Suriname Arbitration]; M/V "Virginia G" (Pan. / Guinea-Bissau), Case No. 19, Judgment of Apr.14, 2014, ITLOS Rep. 4. ๆ 360 [hereinafter M/V "Virginia G"]; Arctic Sunrise Arbitration (Neth. v. Russ.), PCA Case No. 2014-02, Award (Perm. Ct. Arb. 2015) ๆ 192, available at https://pcacases.com/web/sendAttach/1438. [hereinafter Arctic Sunrise Arbitration] 
There is a cardinal distinction between the scope of its jurisdiction under article 288, paragraph 1, of the Convention, on the one hand, and the law to be applied by the Tribunal under the article 293 of the Convention, on the other hand. It also agrees that, to the extent that any aspects of Ireland's claims arise directly under legal instruments other than the Convention, such claims may be inadmissible. ${ }^{34}$

However, the judicial reactions to such propositions suffer from inconsistencies. For example, the UNCLOS Tribunals may take the chance to adjudicate the disputes that do not concern the UNCLOS, as shown in the cases of M/V Saiga, ${ }^{35}$ Guyana v. Suriname Arbitration, ${ }^{36}$ and Virginia $G{ }^{37}$ but may take a conservative approach that Article 293 cannot be used to expand the subject-matter jurisdiction, as shown in Arctic Sunrise Arbitration $^{38}$ and Duzgit Integrity Arbitration. ${ }^{39}$

The $M / V$ Saiga is the first case where the UNCLOS Tribunals expanded the subjectmatter jurisdiction by resorting to Article 293. In this case, Saint Vincent argued that Guinea breached the customary prohibitions on the use of excessive and unreasonable force, ${ }^{40}$ which, according the Tribunal, did not come under the interpretation and application of the UNCLOS. ${ }^{41}$ Yet, the Tribunal found that it had jurisdiction over the use of excessive and unreasonable force by virtue of Article 293, stating:

Although the Convention does not contain express provision on the use of force in the arrest of ships, international law, which is applicable by virtue of article 293 of the Convention, requires that the use of force must be avoided as far as possible and, where force is unavoidable, it must not go beyond what is reasonable and necessary in the circumstances. ${ }^{42}$

The dispositif of the judgement reads as follows: "while stopping and arresting the Saiga, Guinea used excessive force contrary to international law and thereby violated the rights of Saint Vincent and the Grenadines." 43 To emphasize, according to the

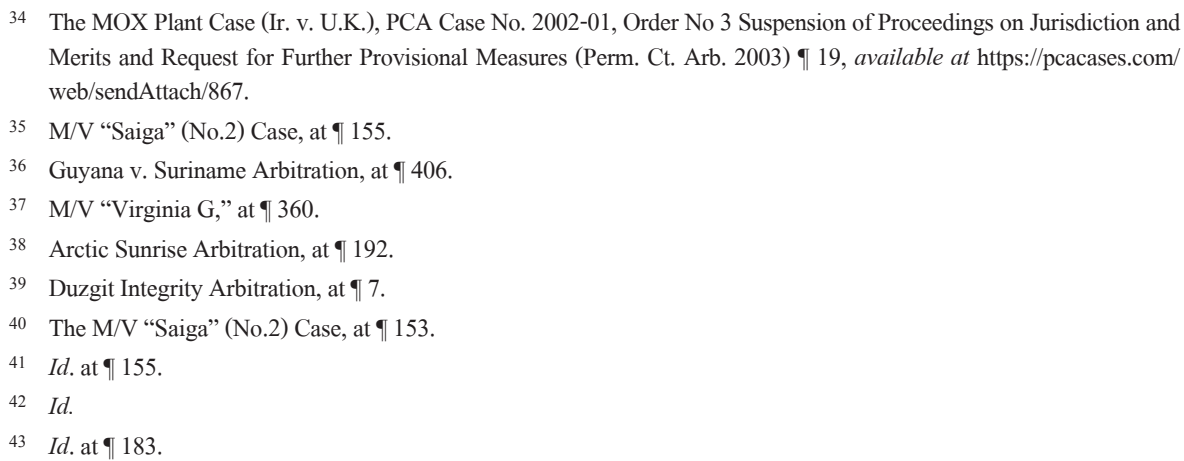


wording of the dispositif, the jurisdiction of the UNCLOS Tribunal in M/V Saiga over the legality of the use of force was not based on any UNCLOS provisions, but was broadly framed by the Tribunal as international law.

Subsequently, the arbitral tribunal in Guyana v. Suriname Arbitration and the ITLOS in Virginia G followed the same approach. In Guyana v. Suriname Arbitration, Guyana asked the arbitral tribunal to adjudicate disputes over "excessive use of force" relating to the UN Charter and general international law. ${ }^{44}$ However, Suriname's submission contended that the arbitral tribunal had no jurisdiction to adjudicate alleged violations of the UN Charter or customary international law; it would require the Tribunal to declare that: "to the extent that Guyana's claims are based on those violations, they must be dismissed. ${ }^{, 45}$ In deciding this dispute, the arbitral tribunal noted that the approach in the $M / V$ Saiga case is a reasonable interpretation of Article 293, whereby Article 293 serves as the jurisdictional basis. The Tribunal finally declared that Suriname had breached the prohibition against the excessive use of force under the UN Charter and customary international law. ${ }^{46}$ In Virginia G, the Tribunal repeated the jurisprudence of $M / V$ Saiga. ${ }^{47}$ Nonetheless, it referred to Article 56(2) of the UNCLOS, which requires that "the coastal State exercise its rights and duties in the exclusive economic zone to have due regard to the rights and duties of other States and thus to proceed with all possible consideration." ${ }^{48}$ In this vein, the Tribunal incorporated the consideration of "excessive force" by the virtue of the words "due regard" under Article 56(2).

However, there is an array of cases explicitly specifying that Article 293 of the UNCLOS cannot expand jurisdiction. For example, in Arctic Sunrise Arbitration, the application of Article 293 was linked to the consideration of whether the Tribunal has the competence to adjudicate on the legality of the exercise of law enforcement operations directly based on human rights law including, inter alia, Articles 9 and 12(2) of the International Covenant on Civil and Political Rights ("ICCPR"). ${ }^{49}$ The Claimant State invoked several human rights standards as applicable to the exercise of law enforcement operations under the ICCPR. ${ }^{50}$ However, the Tribunal rejected

44 Guyana v. Suriname Arbitration, at 9402.

45 Id. at 402.

46 Id. at 406.

$47 \mathrm{M} / \mathrm{V}$ Virginia $\mathrm{G}$, at 9 ๆ $359-60$.

$48 \quad$ Id. at 9349.

49 Arctic Sunrise Arbitration, at 197.

50 The Netherlands, clarified that it "[...] was not inviting the Tribunal to determine that there is a breach of Article 9 and 12.2 of the ICCPR if the Tribunal considers that the content of these provisions, as interpreted and applied by international courts and tribunals, are an integral part of the principle of reasonableness as applicable to law 
this argument. The excerpt in Arctic Sunrise Arbitration, which is in contrast with $M / V$ Saiga, is worth quoting here:

Article 293(1) does not extend the jurisdiction of a tribunal. Rather, it ensures that, in exercising its jurisdiction under the Convention, a tribunal can give full effect to the provisions of the Convention.....Article 293 is not, however, a means to obtain a determination that some treaty other than the Convention has been violated, unless that treaty is otherwise a source of jurisdiction, or unless the treaty otherwise directly applies pursuant to the Convention. ${ }^{51}$

While denying Article 293's effect of jurisdictional expansion, the arbitral tribunal also affirmed the possibility of incorporating the primary rules of international law-for example, human rights obligations as invoked by the Claimant State-to ensure that a tribunal can give full effect to the UNCLOS provisions. Duzgit Integrity Arbitration followed the approach of Arctic Sunrise Arbitration. ${ }^{52}$

\section{A Coherent Approach to Incorporating Other Rules of International Law}

\section{A. Constrained or Liberal? The "Genuine Link Test" for Incorporating Other Rules of International Law}

In judicial practice, international courts can be very liberal to extend the scope of their jurisdiction and the rules they are entrusted to interpret. ${ }^{53}$ Therefore, it is common practice to yield to "the temptation to declare its position on grave matters that are recognized to be beyond its jurisdiction in the specific case before. ${ }^{, 54}$ However, such creativity or capability is constrained. Thirlway noted that the court's jurisdiction is based upon consent and "all judicial jurisdiction derives from treaty law. There is no such thing as jurisdiction deriving from custom or customary international

enforcement actions under the Convention." See Arctic Sunrise Arbitration, Third Supplementary Submission of Netherlands, at $\uparrow 1$.

51 Arctic Sunrise Arbitration, at $\uparrow 192$.

52 Duzgit Integrity Arbitration, at 9208.

53 F. Zarbiyev, Judicial Activism in International Law: A Conceptual Framework for Analysis, 3 J. InT'L DisP. SETTLEMENT 248 (2012).

54 H. Thirlway, International Court of Justice 37 (2016). 
law. ${ }^{, 55}$ In the cases of Oil Platforms, ${ }^{56}$ Application of the Convention on the Prevention and Punishment of the Crime of Genocide, ${ }^{57}$ and Application of the International Convention on the Elimination of All Forms of Racial Discrimination, ${ }^{58}$ the ICJ was involve in multifaceted disputes, with the compromissory clauses confining the jurisdiction of the Court within one particular treaty. In the process of balancing confined jurisdictional balance and the necessity of incorporating other rules of international law, judicial practice has developed an approach known as the "genuine link test."

In the Application of the Convention on the Prevention and Punishment of the Crime of Genocide case, the ICJ noted:

The jurisdiction of the Court in this case is based solely on Article IX of the Convention [...] It follows that the Court may rule only on the disputes between the Parties to which that provision refers [...] It has no power to rule on alleged breaches of other obligations under international law, not amounting to genocide, particularly those protecting human rights in armed conflict. ${ }^{59}$

In the Application of the International Convention on the Elimination of All Forms of Racial Discrimination case, the compromissory clauses also confined the subject-matter of the ICJ to disputes "the interpretation and application" of the Convention on the Elimination of All Forms of Racial Discrimination ("CERD”). Nevertheless, the factual background of this case involves multifaceted disputes concerning human rights law, humanitarian law, and the status of undetermined regimes in international law, so that these subjects are of great complexity and largely go beyond the interpretation and application of the CERD. ${ }^{60}$ As admitted by the ICJ, "one situation may contain disputes which relate to more than one body of law and which are subject to different dispute settlement procedures." ${ }^{.61}$ Moreover, as the jurisdiction of the Court is confined, the questions on jurisdiction and applicable law were the most intractable

\footnotetext{
$55 I d$, at 36. Shaw and Rosenne argued that while the Court has exhibited a flexible attitude to its jurisdiction, it still gives "strict adherence to what parties had agreed in their reference to the Court." See M. SHAw \& S. Rosenne, Rosenne's LaW and Practice of International Court: 1920-2015, 532 (5d ed. 2016).

56 Oil Platforms (Iran v. U.S.), Judgment, 2003 I.C.J. 161 (Nov. 6). [hereinafter Oil Platforms]

57 Application of the Convention on the Prevention and Punishment of the Crime of Genocide (Bosn. \& Herz. v. Serb. \& Montenegro), Judgment, 2007 I.C.J. 43 (Feb. 26).

58 Application of the International Convention on the Elimination of All Forms of Racial Discrimination (Geor. v Russ.), Preliminary Objections, 2011 I.C.J. 70 (Apr. 1). [hereinafter Application of the International Convention on the Elimination of All Forms of Racial Discrimination]

59 Application of the Convention on the Prevention and Punishment of the Crime of Genocide, at 147.

60 Application of the International Convention on the Elimination of All Forms of Racial Discrimination, at 32.

61 Id.
} 
in this case. Put differently, the Court was in a difficult situation when deciding whether and to what extent disputes arose with respect to the "interpretation and application of the CERD." ${ }^{62}$

The jurisdiction of the ICJ also delivered fierce debates among the judges in the case, where several novel arguments were individually proposed by the judges and subsequently endorsed by judicial practice. ${ }^{63}$ In particular, the separate opinion of Judge Koroma supplemented the majority opinion by proposing the "link requirement":

A link must exist between a dispute and the treaty invoked when it is alleged that the legal obligations under the treaty have been violated [...] this limitation is vital. Without it, States could use the compromissory clause as a vehicle for forcing an unrelated dispute with another State before the Court. ${ }^{64}$

It is thus essential to establish the link between disputes and the invoked treaty. Without it, the expansive interpretation of the compromissory clause might cause the ICJ to adjudicate unrelated disputes. ${ }^{65}$ In particular, this limitation applies to whether the jurisdiction of international adjudicatory bodies is confined to "interpretation and application" of particular international instruments such as the UNCLOS dispute settlement procedures. ${ }^{66}$ The "link requirement," proposed by Judge Koroma in his separate opinion, has been incorporated into "jurisprudence constant." Notably, the UNCLOS Tribunals in M/V Lousia and the Chagos Marine Protected Area Arbitration coherently endorsed the link requirement in their jurisprudence.

The ITLOS in $M / V$ Lousia endorsed the view of Judge Koroma in an almost identical wording: "It must establish a link between the facts advanced by Saint

62 The ICJ provided unparalleled detailed arguments on this matter, with more than 100 paragraphs of its judgement examining factual and legal matters relating to the characterisation of disputes. See Application of the International Convention on the Elimination of All Forms of Racial Discrimination, at 9 30-147.

63 For example, the ICJ stated: "[T] claim in circumstances where a response is called for." See id. at $\$ 30$. The legal argument contained in this excerpt was followed by the ITLOS in the recent M/V 'Norstar' case, where the ITLOS held that Italy could not rely upon its silence to cast doubt on the existence of a dispute with Panama. See M/V "Norstar" Case (Pan. v. It.), Case No. 25, 2016, Preliminary Objections of Nov. 4, 2016, \$ 85, available at https:/www.itlos.org/fileadmin/itlos/documents/cases/ case_no.25/Judgment/C25_Judgment_10.04.pdf. The ICJ's Marshall Island judgement also endorsed this position. See Obligations concerning Negotiations relating to Cessation of the Nuclear Arms Race and to Nuclear Disarmament (Marsh. Is v. India), Judgment, 2016 I.C.J. 849, $₫ 37$ (Oct. 5).

64 Application of the International Convention on the Elimination of All Forms of Racial Discrimination, at 9ף 1-7. (Separate opinion of Koroma J.)

$65 \quad$ Id. at 97.

66 UNCLOS art. 288 (1). 
Vincent and the Grenadines and the provisions of the Convention referred to by it and show that such provision can sustain the claim or claims submitted by Saint Vincent and the Grenadines." ${ }^{67}$

In Chagos Marine Protected Area Arbitration, the tribunal endorsed the link requirement in a more implicit manner with a view to preventing the unrelated sovereignty dispute before it. The arbitral tribunal stated:

When the "real issue in the case" [...] do[es] not relate to the interpretation or application of the Convention, however, an incidental connection between the dispute and some matter regulated by the Convention is insufficient [...] Accordingly, the Tribunal finds itself without jurisdiction to address Mauritius' First Submission. ${ }^{68}$

The "genuine link test" is essential for patrolling the boundaries of the tailored structure of the UNCLOS dispute settlement procedures, whereby the links between disputes and the UNCLOS provisions is essential for preventing judicial activism that overrides the consent of States. The question of how to execute such a "genuine link test" in judicial practice, particularly when the other rules of international law apply, is inevitable. The classical example of executing "genuine link test" can find its root in the jurisprudence of the Oil Platforms case.

\section{B. The Execution of the "Genuine Link Test": Lessons from the Oil Platforms case}

The jurisprudence of the Oil Platforms case may illuminate potential solutions for solving the dilemma mentioned above. In this case, the ICJ only had jurisdiction concerning Article X (1) of the 1955 Treaty of Amity between the US and Iran: "Between the territories of the two High Contracting Parties there shall be freedom of commerce and navigation." ${ }^{69}$ The dispute settlement clause was the only basis for jurisdiction, which should limit the scope of the legal assessment made by the Court. However, in light of the fact that the case involved two attacks by the US armed forces destroying a number of Iranian oil production installations in the Persian Gulf, the subject matter of disputes also concerned general international law on the prohibition of the use of force and self-defence. ${ }^{70}$ In this case, the most pressing

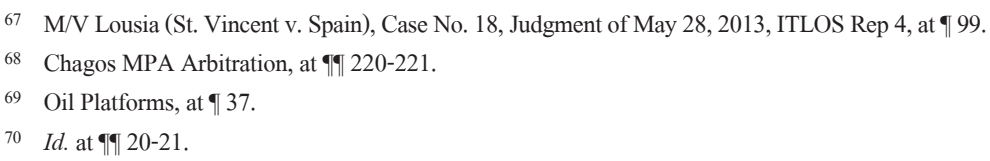


issue was for the ICJ to determine the scope of jurisdiction; specifically, whether general international law on the prohibition of use of force and self-defence could be addressed as an incidental matter in a violation of the Treaty of Amity.

Instead of anchoring other rules in connection to the Treaty of Amity, the ICJ, in its legal reasoning, directly applied general rules on the use of force and self-defence, consequently failing to establish the link between disputes and the provisions of the Treaty of Amity. ${ }^{71}$ Such an expansive approach leads to the criticism that "the Court implicitly held that Iran had a claim against the US, but none on which the Court had jurisdiction in the present proceedings." ${ }^{, 72}$ The ICJ exceeded its judicial mandate by giving reasoning that was not strictly necessary for the adjudication of the disputes. Judges Cannizzaro and Bonafè commented on the Oil Platforms case:

Questions of jurisdiction must certainly be considered with great caution by a judicial body whose jurisdiction depends on the consent of the parties. A cautious approach seems the most opportune at this time in which there is growing fear of an abusive use of compromissory clauses in treaties, [...] which are only remotely connected with it. ${ }^{73}$

The approach of the ICJ in handling jurisdictional issues was harshly contested by many judges on the bench. Since the divergent views among the judges were termed as "formal consensus and substantive dissensus," heavy extra-judicial criticism, being termed as "flawed and ultimately dangerous,",75 "analytical oversimplification," is worth noting that Judge Pieter Kooijmans, in his separate opinion, criticized the approach of the majority opinion:

[...] putting the shoe on the wrong foot. For this is not the claim before the Court, which has to decide whether the actions against the platform can be qualified as

71 Id. at 41. Judge Higgins, in her separate opinion, addressed: "[the Court] has rather invoked the concept of treaty interpretation to displace applicable law." See Oil Platforms, at 94 . (Separate Opinion by Higgins J.)

72 M. Bothe, Oil Platforms Case (Iran v. U.S.), 188 Max Planck Encyclopedia of Public International Law (R. Wolfrum ed., 2011), available at http://opil.ouplaw.com/view/10.1093/law:epil/9780199231690/law-9780199231690-e188.

73 E. Cannizzaro \& B. Bonaf, Fragmenting International Law through Compromissory Clauses? Some Remarks on the Decision of the ICJ in the Oil Platforms Case, 16 Eur. J. InT'L L. 496 (2005).

74 V. Heiskanen, Oil Platform: Lessons of Dissensus, 74 Nordic J. INT'L L. 179-208 (2005).

75 J. Green, The Oil Platforms Case: An Error in Judgment?, 9 J. Confl. Secur. L. 386 (2004).

76 A. Gourgourinis, The Distinction between Interpretation and Application of Norms in International Adjudication, $2 \mathrm{~J}$. InT'L Disp. SeTtLemEnt 33 (2011).

77 P. Kooijmans, The ICJ in the 21st Century: Judicial Restraint, Judicial Activism, or Proactive Judicial Policy, 56 InT'L \& CoMP. L. Q. 752 (2007). 
measures necessary to protect the United States security interests in the sense of Article XX, paragraph 1 (d), of the 1955 Treaty, not whether they were justified as measures taken in self-defence under international law. ${ }^{78}$

Admittedly, the Court may have "no choice but to rely for this purpose on the body of international law." The UN International Law Commission ("ILC") has explicitly acknowledged the view of Judge Kooijmans, echoing the orthodoxy that "general international law provides the background for all application of special law." However, as Judge Kooijmans wrote in his separate opinion, this does not mean that the ICJ can use general international law to replace the relevant provisions. Other rules of international law should merely function as interpretative materials in ascertaining the meaning of treaty provisions. It is the latter approach which is reasonable in establishing a proper jurisdictional basis for any matter. ${ }^{81}$

The jurisprudence mentioned above elucidates the development of a coherent approach towards using other rules of international law in the context of the UNCLOS dispute settlement procedures. Frequently in judicial practice, a single dispute may have links with both the UNCLOS provisions and other rules of international law simultaneously such as environmental law, human rights law, acquisition of territorial sovereignty, and general international law. Hence, the use of other rules of international law is unavoidable. ${ }^{82}$ It would be "putting the shoe on the wrong foot" ${ }^{\prime 83}$ if the UNCLOS Tribunals set aside the detailed scrutiny of the interpreted UNCLOS texts, but apply other rules of international law as substantive. Such ignorance of the genuine links between disputes and the UNCLOS provisions would be unreasonable causing judicial expansion and incoherent jurisprudence.

\section{Applying the "Genuine Link Test": the Examination of the Approaches of the UNCLOS Tribunals}

Applying the "genuine link test" to assess the judicial practice of the UNCLOS dispute settlement procedures reveals that in departing from a more coherent approach of

\footnotetext{
78 Oil Platforms, at 9 23. (Separate Opinion by Kooijmans J.)

79 Id. at 48.

80 Int'l Law Comm'n, Rep. on the Work of its Fifty-Eighth Session, U.N. Doc. A/CN/.4/1.682, at 457.

81 J. Charney, Compromissory clauses and the jurisdiction of the International Court of Justice, 81 AM. J. INT'L L. 85587(1987). See also M. Papadaki, Compromissory Clauses as the Gatekeepers of the Law to be "Used" in the ICJ and the PCIJ, 5 J. INT'L DisP. SETtLement 560-604 (2004); A. Orakhelashivili, Restrictive Interpretation of Human Rights Treaties in the Recent Jurisprudence of the European Court of Human Rights, 4 Eur. J. INT'L L. 529-568 (2001).

82 Wood, supra note 5.

83 Oil Platforms, at $9 \uparrow 42-54$. (Separate Opinion by Kooijmans J.)
} 
using other rules of international law, the UNCLOS Tribunals' judicial practice has been replicating the flawed and unreasonable approach of the Oil Platforms case.

First, the UNCLOS Tribunals' flexible approach of using systematic integration approaches is accompanied by the risk that the vagueness of judicial reasoning may lead to uncertainties and inconsistencies. It must be borne in mind that the systematic integration by international courts and tribunals is subject to State consent. It would also override State consent if the UNCLOS Tribunals apply other rules of international law by virtue of systematic integration that either are irrelevant to the interpretation and application of the UNCLOS provisions, or replace their application. ${ }^{84}$ In addition, such judicial development of open-textured legal norms are occurring without explicit references to systematic integration or Article 31(3)(c) of the VCLT, which results in judicial reasoning lacking cogency and predictability.

Second, the reference rules are subject to divergent interpretations, accompanying the risks of judicial expansion and incoherent jurisprudence. Depending on the judicial interpretation on the rules of references under specific provisions in cases, the UNCLOS Tribunals could refuse to adjudicate certain issues referred to them if the rules of reference were interpreted as affirming that rules and principles continued to be governed by general international law. Conversely, the UNCLOS Tribunals may expand their jurisdiction on the basis of the reference rules. However, this approach risks derogating State consent. As Judges Wolfrum and Cot wrote in their separate opinion, "any attempt to broaden the jurisdictional power of the Tribunal and that of arbitral tribunals under Annex VII going beyond what is prescribed in article 288 of the Convention is not in keeping with the basic philosophy governing the dispute settlement system of the Convention." 85

Third, with regard to broad applicable law, such a flawed approach is reflected in the tribunal's approach in $M / V$ Saiga, whereby the tribunal used international law as its substantive rules of adjudication, but failed to anchor the incorporated rules of international law to specific provisions of the UNCLOS. Similarly, in Virginia $G$, the tribunal should have articulated the meaning of "due regard" at the outset. Then, to establish the link between the dispute on the use of force and this particular legal norm under the UNCLOS, the Tribunal should have situated the other rules of international law incorporated as interpretative materials for determining the meaning of "due regard" under Article 56(2) of the UNCLOS. The Tribunal could have done so, but it did not. In Arctic Sunrise Arbitration, the tribunal fleshed out the

84 Supra note 13 , at 309.

85 “ARA Libertad,” at 9 6. (Joint separate opinion of Wolfrum and Cot J.) 
disagreement with previous judicial interpretation of Article 293 of the UNCLOS. However, such approach of Arctic Sunrise Arbitration has also been criticized. While forbidding the direct application of human rights law, the arbitral tribunal in Arctic Sunrise Arbitration paved the way to indirectly apply human rights law for the purpose of assisting the interpretation of particular legal norms under the UNCLOS. ${ }^{86}$ However, with regard to the incorporation of primary rules of international law, "strait is the gate, and narrow is the way": ${ }^{87}$ the incorporation of the primary rules of international law seems to open a gateway for de facto expansion of the subjectmatter jurisdiction of the UNCLOS Tribunals by incorporating these rules not as interpretative materials but as substantive rules.

In sum, inconsistent and incoherent jurisprudence of judicial bodies has blurred limitations of subject-matter jurisdiction, thereby failing to satisfy the requirement of the "genuine link test." Taken to its extreme, the expansive rewriting of its subjectmatter jurisdiction would undermine the entire legitimacy of the UNCLOS dispute settlement procedures. ${ }^{88}$

\section{Conclusion}

Through judicial interpretation, the UNCLOS dispute settlement procedures serve as the pivotal safeguard for the balance between the rights of coastal States, on the one hand, and the freedoms of other States for their use of the ocean on the other. The process of elaborating on the vague meaning of provisions and developing opentextured legal norms inevitably involves the application of other rules of international law.

The current judicial practice of the UNCLOS Tribunals has blurred the fundamental difference between confined subject-matter jurisdiction and incorporation of other rules of international law that function to interpret the UNCLOS. To solve the problem, a cardinal distinction should be drawn between applying other rules of international law in a manner that replaces the rights and obligations under the UNCLOS, on the one hand, and applying other rules of international law that serve as the interpretative materials used to ascertain the meaning of the UNCLOS provisions, on the other. It is proposed that only the latter approach is feasible in the UNCLOS compulsory

\footnotetext{
6 Arctic Sunrise Arbitration, at $\$ 197$.

87 Matthew 7:14, the Holy Bible (King James Version), available at https://www.kingjamesbibleonline.org/Matthew-7-14.

88 Boyle, supra note 5, at 203.
} 
procedures, since the ability of the UNCLOS Tribunals to apply other rules of international law is essentially determined by Article 288, which confines the subjectmatter jurisdiction to disputes concerning the interpretation and application of the UNCLOS.

It is observed that ICJ judicial practice has developed a "genuine link test" that functions to balance the necessity of incorporating other rules of international law and the obedience to the principle of State consent, which is of great importance for the operations of the UNCLOS dispute settlement procedures.

This study finds that the UNCLOS Tribunals should apply this "genuine link test," i.e., they should establish a genuine link between the disputes and the rules that are being interpreted and applied under the UNCLOS. As part of the interpretation process, the UNCLOS Tribunals should begin by directly interpreting the UNCLOS provisions and articulating and scrutinizing their meaning. This is to guarantee that the use of the wide range of other rules of international law is firmly anchored to specific provisions of the UNCLOS, in order to avoid judicial inconsistency and incoherence and to prevent the derogation of the jurisdictional basis of the tailored UNCLOS compulsory dispute settlement procedures.

Last but not least, the UNCLOS dispute settlement procedures set out four judicial forums in terms of Article 287(1), which are uniformly endowed with compulsory jurisdiction for the disputes settlement which contribute to the judicial development of the UNCLOS. Such an institutional feature has created an invisible community that would ideally lead the UNCLOS Tribunals to develop and follow a uniform approach as to the limits of their subject-matter jurisdiction in order to provide for judicial coherence. In this light, it is an urgent task for the UNCLOS Tribunals to take a pragmatic approach towards the use of other rules of international law in judicial practice, in order to preserve the legitimacy and effectiveness of the UNCLOS dispute settlement procedures. 